\title{
„Literackie dzieciństwo” - w kręgu czytelniczych inicjacji
}

\section{|'Literary Childhood' - in the circle of reading initiations}

\author{
|| Jolanta Ługowska
}

\begin{abstract}
Reading childhood”, which according to some researchers comes to its end when a child turns nine or ten, has an exceptionally important impact on forming literary culture of an adult person. Then in the process of literary initiation, which means shaping of literary needs and habits, an adult reading go-between plays at predominant role. That is the reader who introduces a child into the world of literature and, in large measure, is also responsible for the fact that a future independent reader will associate contact with a book with a feeling of pleasure. An adult reading go-between is also responsible for the proper choice of texts which are read to a child. It is rather a tough task when you take into consideration relatively short period of childhood when diverse reading experiences should be included. It would be optimal to balance the recurring elements with the new ones, take care about gender and stylistic diversity of the presented texts, include both classical works, accompanying many generations of readers, and the contemporary ones.

Key words: children's literature, initiation into literature, an adult reading go-between, oral transmission, book readership
\end{abstract}

Streszczenie: W formowaniu się kultury literackiej człowieka dorosłego niezwykle ważną rolę odgrywa „czytelnicze dzieciństwo”, kończące się, jak twierdzą badacze, około 9 - 10 roku życia. W dokonującym się wówczas procesie literackiej inicjacji, oznaczającej kształtowanie się potrzeb i nawyków czytelniczych, rolę dominującą pełni dorosły pośrednik lektury. On to podejmując się funkcji lektora, wprowadza dziecko w świat książki, a także w ogromnej mierze decyduje o tym, że kontakt z książką kojarzyć się będzie przyszłemu samodzielnemu czytelnikowi z poczuciem przyjemności. Na dorosłym pośredniku lektury spoczywa też obowiązek właściwego doboru tekstów czytanych dziecku, co jest zadaniem trudnym, zwłaszcza gdy weźmie się pod uwagę stosunkowo niedługi okres dzieciństwa, w którym zmieścić się powinny różnorodne czytelnicze doświadczenia. Sytuacją optymalną w doborze dziecięcej lektury wydaje się zrównoważenie elementów powtarzalnych i nowych, zadbanie o zróżnicowanie gatunkowe i stylistyczne prezentowanych tekstów, uwzględnienie zarówno utworów klasycznych, towarzyszących wielu pokoleniom czytelników, jak i współczesnych.

Słowa kluczowe: literatura dla dzieci, inicjacja literacka, dorosły pośrednik lektury, przekaz oralny, czytelnictwo 
W erudycyjnym studium Janusza Dunina poświęconym dziejom polskich publikacji adresowanych do najmłodszych czytelników zwraca uwagę refleksja, która stała się inspiracją, a zarazem punktem wyjścia prezentowanych tu rozważań.

Trzeba pamiętać, że okres dzieciństwa jest krótki, ograniczona jest liczba książek, które można w tym czasie poznać, a jeszcze mniej na zawsze pokochać. Jest to czas, kiedy wszystko jest nowe, a do zaniechanych lektur zwykle się nie wraca - w przeciwieństwie do okresu młodzieżowo-dorosłego, który w czytelnictwie charakteryzują skoki w przód i wstecz (Dunin 1991, 12).

Przytoczona konstatacja bibliofila, bibliologa a ponadto znawcy i miłośnika książki dla dzieci wydaje się niezwykle ważna, zwłaszcza w kontekście rozważań nad miejscem „literackiego dzieciństwa” w całokształcie doświadczeń i kultury literackiej człowieka dorosłego. Kieruje przy tym uwagę czytelnika - pełniącego w obiegu dziecięcym rolę „dorosłego pośrednika lektury" ${ }^{1}$ - na istotną, a zarazem trudną i niejednoznaczną kwestię kryteriów wyboru tekstów, jakie powinny być rekomendowane i prezentowane najmłodszemu odbiorcy, z uwzględnieniem zarówno jego aktualnych kompetencji i zainteresowań, jak również z myślą o przyszłych, dorosłych lekturach i czytelniczych fascynacjach.

W najwcześniejszej, niejako „prerefleksyjnej” fazie inicjacji dziecka w świat książki owo pośrednictwo polega przede wszystkim na głośnej lekturze (bądź recytacji „z pamięci” rymowanek i prostych wierszyków przeznaczonych dla najmłodszych odbiorców), stanowiącej zazwyczaj szczególnego rodzaju komponent ogólniejszego fenomenu - zabawy dorosłego z dzieckiem, w której trójwymiarowy przedmiot semiotyczny, zawierający odpowiednio zakodowany komunikat o charakterze estetycznym, posłużyć może nie tylko do odczytania owych treści, ale również do innych celów, przede wszystkim ludycznych, ściśle złączonych z wyobrażeniem książki jako swoistego substytutu zabawki. O różnego rodzaju „niezaplanowanych” przez nadawcę możliwościach użycia książki w kontekście najwcześniejszych doświadczeń dziecka wspomina Joanna Papuzińska:

Samo udostępnienie dziecku książki bynajmniej nie jest równoznaczne z użytkowaniem jej przez nie zgodnie z jej funkcją i przeznaczeniem. Małe dziecko z reguły traktuje książkę w oderwaniu od jej właściwych funkcji, tj. jako przedmiot stwarzający pewne możliwości manipulacyjne (gniecenie i darcie kartek, stukanie książką o inne przedmioty, wywoływanie hałasu), a nie jako przedmiot niosący znaczenie (Papuzińska 1981, 13).

$\mathrm{Na}$ ten wstępny etap kształtowania się czytelniczych doświadczeń zwraca też uwagę - w nieco innej perspektywie - Janusz Dunin: „Największą

1 Na ważność roli „pośrednika lektury” w procesie komunikacji literackiej z dziecięcym odbiorcą zwraca uwagę Alicja Baluch. Por.: „Mały i niedoświadczony odbiorca (...) z początku przyjmuje w sposób arefleksyjny za dorosłym opiekunem jego wybór lektury i sposób interpretacji (...). Dlatego rola pośrednika jest tak ważna w edukacji literackiej dziecka, tworzy on bowiem pierwszy wzorzec nawyków związanych z lekturą" (Baluch 1987, 45); badaczka podkreśla też konieczność erudycyjnego przygotowania się przez dorosłego do pełnienia tej roli, obejmujacego znajomość podstaw literaturoznawstwa, a także psychologii rozwojowej, pedagogiki, a nawet socjologii, awansując niejako w ten sposób „pośrednika” do rangi „mistrza lektury” (Baluch 2003, 7-8). 
radość sprawia małemu dziecku wspólne z dorosłymi oglądanie, komentowanie i manipulowanie, czyli 'czytanie' nie czytane” (Dunin 1999, 19), dodając do przytoczonej obserwacji charakterystyczną uwagę odnoszącą się do ogólnych reguł uczestnictwa w kulturze literackiej, jakie obowiązują w społeczności osób dorosłych: „Jest to ważny etap. Obserwujemy niekiedy nieporadne obchodzenie się z drukami ludzi starszych, którzy nie przebyli młodzieńczego okresu oswajania się z formą książkowego kodeksu" (Dunin 1999, 19).

Proces, który nazwać można inicjacją literacką dziecka, kończy się, jak utrzymują badacze, zazwyczaj około 9 - 10 roku życia², a za jego zwieńczenie uznać należy osiągnięcie przez odbiorcę poziomu dojrzałości czytelniczej, co w praktyce oznacza zdobycie przez niego kompetencji niezbędnych do samodzielnego kontaktowania się z dziełem literackim. Należą do nich przede wszystkim: przyswojenie technicznej umiejętności czytania (biegłego i ze zrozumieniem), zaistnienie specyficznych potrzeb czytelniczych wspartych doświadczeniem, iż lektura dostarczyć może różnego rodzaju satysfakcji i przyjemności, zdolność do intelektualnego i emocjonalnego zaangażowania w sensy lektury, umiejętność samodzielnego doboru tekstów literackich, stosownie do własnych potrzeb i zainteresowań, uświadomienie sobie (także na podstawie własnych doświadczeń) różnorodności czytelniczych potrzeb (poznawczych, ludycznych i innych), wreszcie gotowość do zaadaptowania nowych funkcji lektury oraz odmiennych od przyswojonych wcześniej kodów literatury (Papuzińska 1981, 15-17). W stosunkowo niedługim okresie „literackiego dzieciństwa” zmieścić się więc musi wiele różnorodnych czytelniczych i „przed-czytelniczych” doświadczeń w znacznej mierze decydujących o formie i zakresie udziału dziecka jako przyszłego dorosłego w kulturze ogólnej, związanej z literaturą „bezprzymiotnikową" - klasyczną i współczesną. Jak bowiem powiada Papuzińska: „Kto nie czyta od najmłodszych lat - nie czyta też w latach dorosłych” (Papuzińska 2007, 38).

Ważnym składnikiem tych najwcześniejszych doświadczeń dziecka związanych z tekstem drukowanym jest przyswojenie sobie przez jego małoletniego użytkownika podstawowych zasad swego rodzaju „czytelniczej etykiety”, oznaczające na początku „intuicję”, później zaś świadomość niezwykłości książki jako przekazu i przedmiotu kultury, jej „niezastępowalności” przez żaden inny nośnik informacji. W wyniku regularnych kontaktów z książką dziecko przyswaja więc sobie i interioryzuje przeświadczenie, że film nie zastąpi książki, a czytanie to nie to samo, co oglądanie. Z czasem odkrywa też, że jedynie książka wiąże się z koniecznością intymnego kontaktu, zakłada całkowite skoncentrowanie się na przedmiocie, w którym zakodowany został literacki komunikat, a zarazem dopuszcza

Punkt docelowy procesu inicjacji literackiej przyjmowany jest jedynie w przybliżeniu, zwłaszcza jeśli weźmie się pod uwagę fakt, że w wielu rzeczywistych czytelniczych biografiach proces ów nie zostaje w ogóle zakończony; obserwowane jest - występujące niekiedy nawet w okresie metrykalnej dojrzałości - zjawisko swoistego regresu czytelniczych potrzeb i kompetencji (Papuzińska 1981, 17 i nast.). 
możliwość indywidualnego wyboru miejsca i czasu lektury, dzielenia jej na dowolne odcinki jak również przyjęcie optymalnego dla siebie tempa czytania. Intymność kontaktu z książką oznacza też możliwość zastosowania przez adresata różnego rodzaju strategii odbiorczych: przeglądania, czytania (niekiedy wielokrotnego) jedynie wybranych fragmentów oraz pomijania innych. Suwerenność czytelnika, jego niezależność od dyktatury czasu, tempa i kolejności emisji obowiązującej w kinie, radiu, teatrze czy telewizji dopuszczają także naruszenie zasady czytania „linearnego” wyrażające się na przykład w cofaniu się do już przeczytanych fragmentów w celu przypomnienia sobie bądź wyjaśnienia miejsc niejasnych, lub też w „ukradkowym” zaglądaniu do zakończenia utworu, by niejako „przed czasem” upewnić się, że ulubionemu protagoniście nic złego się nie stało (Papuzińska 1981, 19-20).

W porównaniu z przekazem audiowizualnym książka (nawet zawierająca bogaty materiał ilustracyjny) uruchamia, by posłużyć się określeniem Papuzińskiej, „aktywność wyobrażeniową”, dopuszcza zatem znaczną swobodę interpretacyjną, zachęca niejako do własnych czytelniczych konkretyzacji odnoszących się do literackich postaci, miejsc i pejzaży, w jakich rozgrywa się akcja. Te tradycyjne właściwości książki, decydujące o jej wyjątkowości i wspomnianej już „niezastępowalności” przez inne przedmioty kultury, wydają się szczególnie ważne współcześnie, gdy pierwszym w porządku indywidualnych doświadczeń „środowiskiem kulturalnym” dziecka okazują się często nie książki (nawet jeśli uwzględni się adresowane do coraz młodszych dzieci, także przeznaczone dla niemowląt, książki-zabawki), lecz odbiorniki telewizyjne, kasety, audiobooki, tablety i smartfony. Otaczający nas świat mediów elektronicznych stawia więc dorosłego pośrednika lektury wobec nowych zadań nieznanych w przeszłości, gdy literatura oraz tradycyjny przekaz oralny stanowiły jeszcze w XIX wieku jedyne, zaś w pierwszej połowie następnego stulecia nadal dominujące formy komunikacji. Zadania te polegają dziś przede wszystkim na wyodrębnieniu swoistego fenomenu książki z coraz bogatszej oferty mass mediów, a zarazem na przekonaniu odbiorcy o jego wyjątkowości i różnego rodzaju satysfakcjach wiążących się z samodzielnym kontaktowaniem się z medium pisma oraz druku, i w ten sposób „przywrócenia” go młodemu czytelnikowi jako formy zaspokajania specyficznych, zwanych jeszcze niekiedy „wyższymi”, potrzeb duchowych, z nadzieją, że okazać się ona może „konkurencyjna” wobec łatwiejszych w recepcji form wiążących się z kulturą obrazka. Warto przy tym zauważyć, że rozpoznanie specyficznych funkcji książki w sferze intuicyjnej następuje, zanim jeszcze dziecko zostaje samodzielnym czytelnikiem. Wspomniana wcześniej intymność lektury staje się bowiem udziałem najmłodszego odbiorcy już wówczas, gdy wraz z dorosłym pozostaje w fizycznym kontakcie z książką, może jej dotykać, przewracać kartki, oglądać i komentować ilustracje, a także, do pewnego stopnia, uczestniczyć w procesie głośnej lektury, na przykład inicjując ją bądź przerywając 
lub też sygnalizując potrzebę powrotu do wybranego fragmentu już przeczytanego, co wydaje się charakterystycznym pogłosem „odwiecznego” rytuału opowiadania ustnego ${ }^{3}$. Dziecko niejako od początku swych kontaktów z książką nie jest więc jedynie biernym odbiorcą przekazywanych mu komunikatów, stara się wpływać na ich formę i treść, odczuwając przy tym satysfakcję, gdy odkrywa, że dorosły pośrednik lektury (zazwyczaj w roli tej występuje jedno z rodziców) dzieli jego upodobania i preferencje ${ }^{4}$. Kojarzenie książki z kojącą obecnością bliskiej osoby a także z możliwością przeżywania pozytywnych emocji wiążących się ze śledzeniem losów bohaterów stanowi więc elementarny składnik procesu czytelniczej inicjacji, sprawiający, iż w doświadczeniu dziecka czytanie jawi się jako czynność sprawiająca zmysłowo wręcz uchwytną przyjemność ${ }^{5}$. Jest ona jednym z najważniejszych rodzinnych rytuałów służących między innymi przejściu granicy między dniem a snem, sposobem spędzania wolnego czasu, często formą nagrody za dobre wywiązanie się z własnych obowiązków.

Proces inicjacji literackiej dziecka nie ogranicza się jednak do utrwalenia nawyku kontaktów z książką, postrzeganego jako źródło doznań przyjemnych, aczkolwiek jego znaczenia dla całokształtu literackiej edukacji nie sposób przecenić. Najważniejszym i ostatecznym celem tego procesu jest przygotowanie dziecka do czytelniczej samodzielności oznaczającej gotowość do podejmowania przez nie coraz bardziej złożonych zadań i ról czytelniczych. Wiąże się ona z koniecznością osiągnięcia przez przyszłego pełnoprawnego użytkownika tekstów drukowanych odpowiedniego poziomu erudycji i nabycia przez niego kompetencji niezbędnych do rozpoznania i docenienia różnorodności form i typów literatury, z jakimi zetknąć się on może w wieku dojrzałym. Inaczej rzecz ujmując, w refleksji nad możliwymi formami literackiej inicjacji małoletniego odbiorcy uwzględnić trzeba zarówno jego aktualne możliwości wynikające w znacznej mierze z usytuowania w samym centrum świata „wielkiej zabawy”, jak i perspektywę przyszłego, na prawach dorosłego, uczestniczenia przez niego w kulturze literackiej. Obok radości czytania, kojarzącej się przede wszystkim ze stanem „tu i teraz”, pojawić się więc musi w tym swoistym projekcie inicjacji pojęcie kulturowej powinności antycypującej czytelniczą dojrzałość dziecka

3 Oralny model opowiadania, ze szczególnym wyeksponowaniem funkcji dziecka, które słucha, komentuje i proponuje zmiany w narracji dorosłego, rekonstruuje w jednym ze swych tekstów „zakorzenionych w dzieciństwie” Tove Jansson. Por.: „'Była sobie raz mała dziewczynka niezwykłej wręcz urody, którą mama wręcz niezmiernie kochała...' Dziecko skinęło głową z powagą i podziwem. Tak lepiej, powiedziało. Nie zmieniaj początku. Potem może się dziać, co tylko chce" (Westin 2012, 375).

4 Na potrzebe swoistej syntonii w zakresie czytelniczych emocji dziecka i dorosłego zwraca uwage, w kontekście rozważań nad baśnią, Bruno Bettelheim, stwierdzając, iż dla dziecka ważne jest potwierdzenie, że „rodzice dzielą jego uczucia, skoro lubią tę samą baśń” (Bettelheim 2010, 44).

5 Charakterystyczne pod tym względem wydają się też refleksje autotematyczne, odnoszące się do preferencji lekturowych bohaterów i stosowanych przez nich sposobów lektury, w utworach beletrystycznych adresowanych do młodego odbiorcy. Szczegółowe opisy lektury mające na celu potwierdzenie i uwiarygodnienie przeżywanej przez fikcyjne postaci radości czytania należą do głównych wątków cyklu Jeżycjada Małgorzaty Musierowicz (Ługowska 2011).

6 Na rolę zabawy i możliwość potraktowania jej jako paradygmatu subkultury dziecięcej zwrócił uwagę Jerzy Cieślikowski: „Wszystko, co dzieci wzięły od dorosłych, co dla nich dorośli stworzyli, co same wymyśliły i wreszcie co dorośli dla nich napisali najlepszego, służy przede wszystkim i w pierwszym rzędzie zabawie. To jest wielkie hasło i emblemat, pod którym dziecko bawi się, a więc tworzy, reprodukuje, upaja się i igra słowem" (Cieślikowski 1967, 7). 
i zapowiadającej niejako jego przyszłe obowiązki wiążące ze społecznym statusem osoby wszechstronnie oczytanej.

Świadomość istnienia tych dwu, w pewnej mierze antagonistycznych, komponentów interesującego nas procesu prowadzenia małoletniego odbiorcy do czytelniczej dojrzałości każe też baczniej przyjrzeć się wspomnianej już kwestii decyzji związanych z doborem tekstów literackich, które już w najwcześniejszej fazie inicjacji dotrzeć powinny do dziecka, stając się przedmiotem różnego rodzaju „czytań domowych”. Stroną uprzywilejowaną przy podejmowaniu owych decyzji są oczywiście dorośli: to oni kierując się własnym gustem, często doświadczeniami lekturowymi wyniesionymi ze swego dzieciństwa, kupują dzieciom książki, które sami akceptują (Dunin 1999, 7-8), uznając, że spełnią one oczekiwania także kolejnego, najmłodszego, pokolenia czytelników. Materialny efekt podjętych decyzji stanowią rodzinne księgozbiory stanowiące zarazem dla „aktualnych” dzieci bazę, na podstawie której dokonują własnych wyborów, wyrażających się najczęściej w prośbach o przeczytanie, po raz kolejny, tego samego wiersza lub bajki. Zjawisko wspomnianych lekturowych powrotów znamionujące zdaniem Bettelheima związek między światem przedstawionym poszczególnych utworów (w analizowanym przez niego przypadku konkretnych wątków ludowych baśni) a własnymi problemami, dylematami i rozterkami, często o charakterze nieświadomym, przeżywanymi przez dziecko ${ }^{7}$, można jednak wyjaśnić, nie odwołując się do założeń psychoanalizy. Czytelnicze przywiązanie do konkretnej opowieści świadczy bowiem nie tylko o funkcjonowaniu charakterystycznego dla recepcji dziecięco-młodzieżowej mechanizmu projekcji-identyfikacji, polegającego na „umieszczaniu bez zastrzeżeń siebie w bohaterze baśniowym" (Bettelheim 2010, 32), ale przede wszystkim na oczekiwaniu ponownego przeżycia doświadczonych wcześniej emocji związanych z lękiem o los bohatera oraz radością, gdy opowiadanie zmierzało do happy endu. Przywiązanie do wybranych fabuł czy ulubionych wierszy stanowi więc, niezależnie od możliwych głębszych, psychologicznych motywacji, przede wszystkim potwierdzenie kierowania się przez dziecko w wyborze i sposobie recepcji utworów literackich potrzebą przyjemności płynącą, między innymi, z przewidywalności, jaką zapewniają teksty oparte na tych samych wzorcach i schematach konstrukcyjnych. Czy można jednak przez całe życie czytać „tę samą” książkę? Zapewne jest to możliwe, co więcej, zdają się tę możliwość potwierdzać konkretne biografie metrykalnie dorosłych czytelników, którzy bogatą, wieloskładnikową „strawę duchową”, jaką oferuje literatura, ograniczyli do „jednej potrawy”: ulubionej baśni o Kopciuszku rozgrywającej się w coraz to innych, zmieniających się dekoracjach, czy o niekończących się przygodach „wiecznego chłopca” w szerokim świecie pełnym frapujących

Por.: „Ponieważ nie możemy wiedzieć, jaka baśń będzie dla konkretnego dziecka najważniejsza w danym okresie życia, nie możemy też sami decydować, jaką baśń i dlaczego mamy mu w określonym momencie opowiadać. Rozstrzygać o tym może jedynie samo dziecko, ujawniając uczucia, jakie budzi dana baśń w świadomej i nieświadomej sferze jego umysłu (...) czy też prosząc o powtarzanie opowieści” (Bettelheim 2010, 43). 
zagadek, nieoczekiwanych zasadzek i wciąż nowych wyzwań. Świadczą one o rozpoznaniu przez odbiorców tylko jednej, wybranej - kompensacyjnej i ludycznej - funkcji literatury i stosowaniu przez nich w recepcji tego samego typu czytelniczej konkretyzacji, w konsekwencji więc o swoistym „uwięzieniu” w odbiorczych stereotypach. Z tego też przede wszystkim powodu oparte na empatii i zrozumieniu aktualnych potrzeb i zainteresowań młodego czytelnika, ale też kompetentne, odwołujące się do wiedzy i doświadczenia odbiorcy dojrzałego, pośredniczenie w procesie dziecięcej lektury, pełnienie w niej przez dorosłego funkcji, by użyć określeń Alicji Baluchowej, „mistrza” i „przewodnika”, nie może ograniczyć się do towarzyszenia dziecku i bez zastrzeżeń aprobowania jego czytelniczych wyborów. W relatywnie krótkim okresie czytelniczego dzieciństwa młodociany odbiorca powinien więc mieć szansę zetknięcia się z jak najszerszą reprezentacją zróżnicowanych wzorców artystycznego mówienia, związanych z poszczególnymi epokami i stylami ukształtowanymi w historii literatury.

Wsparcie dla tego postulatu odnaleźć można, paradoksalnie, w słynnym wywodzie Tolkiena o braku „naturalnego związku” między baśniami i dziećmi, który zakończony został przez autora Władcy pierścieni charakterystyczną pointą: [Dzieci] „Są młode i rosną, i mają zazwyczaj doskonały apetyt, a więc bez większego trudu przełkną i baśnie” (Tolkien 1994, 39). Ten właśnie „apetyt” kilkulatka oznaczający gotowość do poznawczego skonfrontowania się z nieznanymi wcześniej modelami świata przedstawionego oraz do przyswojenia sobie wzorców wypowiedzi odmiennych od konwencjonalnych, obowiązujących w języku codziennej komunikacji, jak również charakterystyczny dla wieku dziecięcego brak uprzedzeń i przejawów snobizmu, zdaje się świadczyć o potrzebie (i możliwości) stałego wzbogacania „menu”, nawet jeśli niektóre z jego składników nie zostaną przez dziecko od razu zaakceptowane. Obok wspomnianych już baśni i bajek przedmiotem dziecięcej lektury stać się więc powinny utwory nawiązujące do założeń realizmu jako metody twórczej, wykorzystywanej zarówno w opowiadaniach i - adresowanych do nieco starszego odbiorcy - powieściach obyczajowych o tematyce współczesnej, jak i w epice historycznej.

Dla przyszłego czytelnika poezji - także współczesnej - niezwykle ważne wydaje się zapoznanie go w fazie inicjacyjnej z różnymi odmianami wiersza (sylabotonicznego, tonicznego, nieregularnego i wolnego), z podstawowymi systemami metrycznymi i rodzajami strofy. Ważnym odkryciem młodego odbiorcy może się stać uświadomienie sobie, iż wiersz skierowany być może „do ucha” bądź „do oka” (Cieślikowski 1975, 207), ujawniając pełnię swych artystycznych walorów w procesie słuchania, gdy operuje wyrazistym schematem rytmicznym, onomatopejami i rymami, lub patrzenia - gdy niezwykłość artystycznego pomysłu realizuje się na przykład w sferze użycia znaków literowych jako piktogramów, będącej swoistą syntezą pomysłów literackich, graficznych i edytorskich (Cieślikowski 1975, 219). W realizacji postulatu wszechstronności i wewnętrznego zróżnicowania materiału 
literackiego przeznaczonego dla najmłodszego odbiorcy istotną rolę odegrać mogą popularne antologie, zwłaszcza zawierające utwory pochodzące z różnych epok, reprezentujące zróżnicowane modele komunikacyjne oraz towarzyszące im założenia i intencje autorskie. Joanna Papuzińska podkreślając ich szczególną użyteczność w kształtowaniu przyszłych nawyków lekturowych dziecka i zakorzenienie w czasoprzestrzeni dzieciństwa, snuje na ich podstawie refleksję nad idealną Księgą Domową, będącą „oknem wystawowym” literatury dziecięcej, gdzie znajduje swe miejsce „reprezentacja różnych form i tematów literackich, nazwiska najważniejszych twórców, bogactwo nastrojów i stylów literackich" (Papuzińska 2007, 36).

Zasada reprezentatywności antologii wobec dziejów literatury dziecięcej zachowana została w najwyższym stopniu w poprzedzonych erudycyjnymi wstępami zbiorach stanowiących w gruncie rzeczy kompendia wiedzy o poezji dziecięcej adresowane przede wszystkim do odbiorcy dorosłego. Należą do nich: ciesząca się dużą popularnością, trzykrotnie wznawiana Antologia poezji dziecięcej w wyborze i opracowaniu Jerzego Cieślikowskiego (Cieślikowski 1980, 1982, 1991) oraz Poezja dla dzieci. Antologia form i tematów w opracowaniu Ryszarda Waksmunda (Waksmund 1999). Druga z wymienionych pozycji stanowi równocześnie próbę typologicznego uporządkowania twórczości poetyckiej przeznaczonej dla dziecka, uwzględniającą zarówno różne modele komunikacyjne w niej realizowane, jak i dominujące $\mathrm{w}$ pisarstwie dla najmłodszych tematy. Wzięte zostały pod uwagę różne odmiany wierszy „dla dzieci” (na przykład moralizatorskie, edukacyjne, dedykacyjne), „dziecięce” (np. wiersze do gier i zabaw), przykłady „liryki dla dzieci” i liryki „dziecięcej”, także twórczość poetycka samych dzieci i teksty folklorystyczne, wreszcie wybrane utwory dla dorosłych wykorzystujące tematy związane z dzieckiem i dzieciństwem.

Podział „tematyczny” umożliwił autorowi antologii umieszczenie obok siebie autorów należących do różnych epok w historii literatury. W rozdziale zawierającym „wiersze o lekturze” odnajdziemy więc między innymi utwory Stanisława Jachowicza, Marii Konopnickiej, Czesława Janczarskiego, Witolda Zechentera i Joanny Papuzińskiej, które to zestawienie umożliwi świadomemu, odpowiednio przygotowanemu czytelnikowi prześledzenie fenomenu stałości i zmienności w ujęciu przez poetów jednego z uniwersalnych tematów literatury dziecięcej, dziecku zaś uzmysłowi, że ten sam temat można przedstawić w sposób poważny albo ludyczny, realistyczny lub baśniowy, w konwencji pedagogicznego napomnienia bądź poetyckiego żartu i zabawy słowem. Układ tematyczny antologii skonfigurowany z chronologicznym umożliwia też wyeksponowanie ponadhistorycznego zasięgu określonych modeli komunikowania się z dziecięcym odbiorcą. Dziecięcy autodydaktyzm okazuje się więc pedagogiczną strategią znaną już Jachowiczowi, twórczo rozwijaną w wierszach Konopnickiej, Oppmana, Tuwima, 
Gałczyńskiego, Brzechwy, Kerna i Wawiłow. Wydana w serii I renomowanej Biblioteki Narodowej Antologia poezji dziecięcej Cieślikowskiego zachowuje natomiast tradycyjny, typowy dla antologii wieloautorskich układ chronologiczny, wyraźnie podporządkowując koncepcję tomu (zawiera on erudycyjny wstęp, noty biograficzne i indeksy) potrzebom i oczekiwaniom badacza literatury dziecięcej. Warto jednak przypomnieć, że antologia opracowana przez autora Wielkiej zabawy stała się też bazą dla wyboru sporządzonego z myślą o młodym odbiorcy, opublikowanego pod tytułem „Pojedziemy w cudny kraj...”. Wiersze dla dzieci, pod względem edytorskim przypominającego typowe, bogato ilustrowane książki dla dzieci ${ }^{9}$, umożliwiające dziecięcemu czytelnikowi zetknięcie się z twórczością autorów dawnych i współczesnych, uprawiających różne typy i odmiany poezji.

Strategia literackiej inicjacji oznaczać więc powinna możliwość przemierzania przez adepta sztuki czytania różnych dróg i dróżek, zarówno tych wiodących w przeszłość, prowadzących do spotkania z odmiennymi od własnej typami kultur (na przykład z tradycyjną kulturą ludową), jak i zmierzających w stronę artystycznego nowatorstwa. Ważna wydaje się przy tym różnorodność prezentowanej dziecku oferty kulturowej, w której znalazłoby się miejsce zarówno dla tekstów klasycznych (w tym Chorego kotka, Stefka Burczymuchy czy W Wojtusiowej izbie), znanych i cenionych przez pokolenia rodziców i dziadków, jak i dla wybranych utworów autorów współczesnych, realizujących nowe wzorce artystycznego mówienia na przykład dla Józefa Ratajczaka, Danuty Wawiłow czy Joanny Kulmowej ${ }^{10}$. Optymalną sytuacją wydaje się przy tym zrównoważenie w procesie inicjacji literackiej elementów powtarzalnych i nowych, umożliwiające małemu odbiorcy przeżycie radości czytania i związanego z nim poczucia relaksu, a zarazem odkrywanie nowych możliwości artystycznej ekspresji, nawet jeśli te odkrycia zostaną na razie „odłożone na bok”, pozostając jak gdyby na skraju świadomości dziecka.

\section{Bibliografia:}

Antologia poezji dziecięcej, 1991, Cieślikowski J. (wybór i oprac.), Wrocław. Baluch Alicja, 1987, Dziecko i świat przedstawiony czyli tajemnice dziecięcej lektury, Warszawa.

Baluch Alicja, 2003, Od ludus do agora. Rozważania o ksiązkach dla młodzieży i o sposobach lektury, które wioda od zabawy do poważnej rozmowy o literaturze, Kraków.

Baluch Alicja, 2005, Książka jest światem. O literaturze dla dzieci małych oraz dla dzieci starszych i nastolatków, Kraków.

\footnotetext{
8 O różnych postaciach i formach dydaktyzmu pisze Bogusław Żurakowski, dostrzegając w dawnej i współczesnej poezji dla dzieci obecność dwu postaci tradycji: dydaktycznej i lirycznej, przy czym starsza z nich dydaktyczna - nie zanika bynajmniej we współczesności, a nawet występuje we współczesnej poezji dla dzieci w postaci „czystej” (Żurakowski 1975, 11 i nast.).

9 W przygotowaniu tego tomu miały udział córka - ilustratorka książki oraz wnuczki Cieślikowskiego, których opinie uwzględnione zostały przy wyborze wierszy (Cieślikowski 1992, 6).

10 Cenne sugestie dotyczące wyboru tekstów, dawnych i współczesnych, adresowanych do młodego odbiorcy odnaleźć można w: Baluch 2005.
} 
Bettelheim Bruno, 2010, Cudowne i pożyteczne. O znaczeniach i wartościach baśni, Danek D. (przeł.), Warszawa.

Cieślikowski Jerzy, 1967, Wielka zabawa. Folklor dziecięcy, wyobraźnia dziecka, wiersze dla dzieci, Wrocław.

Cieślikowski Jerzy, 1975, Literatura i podkultura dziecięca, Wrocław.

Dunin Janusz, 1991, Książeczki dla grzecznych i niegrzecznych dzieci. Z dziejów polskich publikacji dla najmłodszych, Wrocław.

Ługowska Jolanta, 2011, O rozkoszach płynacych z czytania. Obrazy lektury w powieściach dla młodzieży Małgorzaty Musierowicz, w: Łeńska-Bąk K., Sztandara M. (red.), O rozkoszach wszelakich... Od przyjemności do ekstazy w kontekstach kultury, Opole, s. 103-113.

Papuzińska Joanna, 1981, Inicjacje literackie dziecka. Problemy pierwszych kontaktów dziecka z książka, Warszawa.

Papuzińska Joanna, 2007, Dziecięce spotkania z literatura, Warszawa.

Poezja dla dzieci. Antologia form i tematów, 1999, Waksmund R. (oprac.), Wrocław.

„Pojedziemy w cudny kraj...”. Wiersze dla dzieci, 1992, Ługowska J.

i Waksmund R. (wstęp i wybór), Wrocław.

Tolkien John R.R., 1994, Drzewo i liść oraz Mythopoeia, Kokot J., Obarski M., Sokołowski K. (przeł.), Poznań.

Westin Boel, Tove Jansson mama Muminków, 2012, Ratajczak B. (przeł.), Warszawa.

Żurakowski Bogusław, 1975, Elementy tradycji w poezji dla dzieci, w: Skrobiszewska H. (red.), O literaturze dla dzieci i młodzieży. Studia, rozprawy, szkice, Warszawa.

\section{O Autorce:}

Jolanta Lugowska - prof. zw. dr hab., pracuje w Instytucie Filologii Polskiej Uniwersytetu Wrocławskiego. Zainteresowania badawcze: literatura współczesna, problemy kultury ludowej i folkloru widziane z perspektywy literaturoznawcy - tekstologa i genologa, zagadnienia literatury dla dzieci i młodzieży, relacje między literaturą i kulturą wysokoartystyczną, ludową, popularną i dziecięcą. Autorka książek: Ludowa bajka magiczna jako tworzywo literatury (Wrocław 1981); Bajka w literaturze dziecięcej (Warszawa 1988), W kręgu ludowych opowiadań. Teksty, gatunki, intencje narracyjne (Wrocław 1993), Folklor - tradycje - inscenizacje. Szkice literacko-folklorystyczne (Wrocław 1999), W Fantazjanie i gdzie indziej. Szkice o baśni literackiej (Wrocław 2006) oraz ponad 150 artykułów. Redaktor naczelna dwumiesięcznika „Literatura Ludowa”. 